\title{
Distribution and occurrence of microsporidian pathogens of the willow flea beetle, Crepidodera aurata (Coleoptera: Chrysomelidae) in North Turkey
}

\author{
Mustafa Yaman, Gönül Algı, Beyza Gonca Güner \& Sabri Ünal
}

\begin{abstract}
Yaman, M., Alg1, G., Güner, B. G. \& Ünal, S. 2015: Distribution and occurrence of microsporidian pathogens of the willow flea beetle, Crepidodera aurata $(\mathrm{Co}-$ leoptera: Chrysomelidae) in North Turkey. - Entomol. Fennica 26: 171-176.

In this study, microsporidian pathogens in Crepidodera aurata populations were investigated. Totally $1,728 \mathrm{C}$. aurata adults were examined for microsporidian pathogens and 78 of them were found to be infected. Two species of microsporidia; Microsporidium sp.1 and Microsporidium sp. 2 were observed in the $C$. aurata populations from ten localities in North Turkey. They show considerable difference from each other in the spore morphology and dimension, infection rate and host locality. The spores of Microsporidium sp. 1 were oval in shape and measured from 3.66 to $5.66 \mu \mathrm{m}$ in length and from 1.35 to $2.22 \mu \mathrm{m}$ in width $(\mathrm{n}=50)$. The spores of Microsporidium sp. 2 were slightly curled and measured from 2.44 to $3.55 \mu \mathrm{m}$ in length and from 1.25 to $1.55 \mu \mathrm{m}$ in width $(\mathrm{n}=50)$. These microsporidia were recorded from $C$. aurata for the first time. Here we present occurrence and distribution of two microsporidia in C. aurata populations as natural potentially suppressing factors.
\end{abstract}

M. Yaman, G. Algı \& B. G. Güner, Department of Biology, Faculty of Science, Karadeniz Technical University, 61080, Trabzon, Turkey; Corresponding author'se-mail:muyaman@hotmail.com

S. Unal, Department of Forest Engineering, Faculty of Forestry, Kastamonu University, Kastamonu, Turkey

Received 11 March 2015, accepted 2 June 2015

\section{Introduction}

The family Chrysomelidae, one of the largest families of the order Coleoptera, includes phytophagous insects. A member of this family, the willow flea beetle Crepidodera aurata Marsham is a widely distributed species (Aslan et al. 2004, Urban 2011). This species naturally occurs in Europe, northern Africa, Caucasus, Anatolia (Turkey), Iran, Kazakhstan, Siberia, Mongolia, China and Korea (Aslan et al. 1999, Aslan \& Warchalowski 2005, Baselga \& Novoa 2007, Bukejs
2009, Urban 2011). It is an important pest species of poplars and willows in different countries (Aslan et al. 1999, Mikhailov \& Hayashi 2002, Czerniakowski 2005, Urban 2011). Urban (2011) mentioned that this species is the most important species of the genus in forestry. Alternative to pesticides, biological control strategies or suppressing factors have not been yet searched to find possible effective methods to struggle this pest.

The members of the family Chrysomelidae are frequently infected by pathogenic protists. 


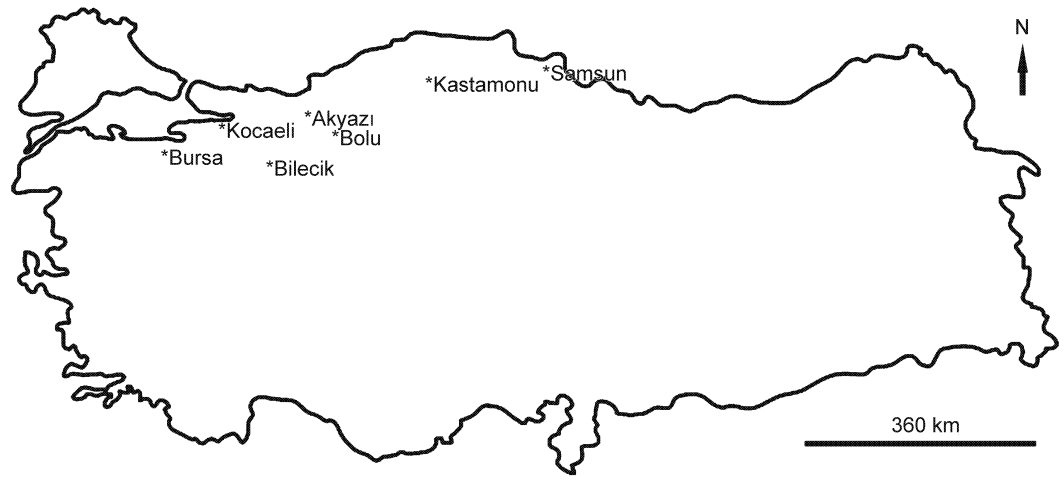

Fig. 1. Localities in where Crepidodera aurata adults were collected in Turkey.
Pathogenic and parasitic organisms infecting this family have aroused interest as potentially suppressing factors of chrysomelid populations (Toguebaye et al. 1988, Poinar 1988, Theodorides 1988, Hokkanen \& Lipa 1995, Yaman 2002a,b, 2004, 2007, 2008, Yaman \& Radek 2003, Martin et al. 2004, Ertürk et al. 2008, Yaman et al. 2008a, 2011a,b). Several new pathogen species from different groups have been isolated and characterized from these insects recently (Yaman \& Radek 2003, Yaman et al. 2008b, 2010). However, there is no record on the entomopathogenic protists infecting C. aurata.

In the present study we aimed at searching for the first time microsporidian pathogens and documenting their occurrence and distribution in the populations of $C$. aurata as natural potentially suppressing factors of this important pest.

\section{Materials and methods}

\subsection{Insect samples}

Totally 1,728 C. aurata adults were collected from a wide geographical area (especially most poplar breeding areas from a piece of land of $779,000 \mathrm{~km}^{2}$ ) with a high sampling ratio (10 localities and 26 samplings) in Turkey from April to September during 2013 and 2014 (Fig. 1).

\subsection{Microscopic examination}

Each of $C$. aurata adults was placed individually into a small drop of water on a microscopic slide and dissected in Ringer's solution by using dis- section pins. Wet smears were examined under a microscope for identification of microsporidian pathogens. When an infection was observed, the slides were air-dried and fixed with methanol for $3 \mathrm{~min}$. They were then washed with distilled water, stained for approximately ten hours in freshly prepared $5 \%$ solution of Giemsa stain, washed in running tap water and air-dried (Toguebaye et al. 1988). Giemsa-stained preparations were then carefully re-examined under a microscope. Detected fresh and stained spores were measured and photographed using an Olympus BX51 microscope with a DP-25 digital camera and a DP2BSW Soft Imaging System.

\section{Results}

During the study, two possibly new microsporidian species were observed in the $C$. aurata populations. These microsporidia showed considerable difference in the spore morphology. The first Microsporidium (Isolate 1) was observed in Vezirköprü, Samsun provience. The spore of this microsporidium was oval in shape and measured from 3.66 to $5.66 \mu \mathrm{m}$ in length and from 1.35 to $2.22 \mu \mathrm{m}$ in width $(n=50)$. The second microsporidian species (Isolate 2) was observed in the rest of the investigated localities. The spore of this microsporidium was slightly curled and measured from 2.44 to $3.55 \mu \mathrm{m}$ in length and from 1.25 to $1.55 \mu \mathrm{m}$ in width $(n=50)$.

We observed microsporidial infections in seven of the ten investigated localities in the both years (Table 1). Isolate 1 showed infection from 1.7 to $5 \%$ and isolate 2 from 0.8 to $25 \%$. Total infection was $5.4 \%$ in 2013 and $4.5 \%$ in 2014 . The 
Table 1. Occurrence of microsporidian pathogens in populations of Crepidodera aurata (Coleoptera: Chrysomelidae) in Turkey.

\begin{tabular}{|c|c|c|c|c|}
\hline Locality & $\begin{array}{l}\text { No. of examined } \\
\text { beetles }\end{array}$ & $\begin{array}{l}\text { Sampling } \\
\text { date }\end{array}$ & $\begin{array}{c}\text { No. of } \\
\text { infected } \\
\text { beetles }\end{array}$ & $\begin{array}{l}\text { Infection } \\
\text { rate (\%) }\end{array}$ \\
\hline \multicolumn{5}{|l|}{ Samsun } \\
\hline \multirow{2}{*}{ 1-Vezirköprü } & 118 & 25.4.2014 & 2 & 1.7 \\
\hline & 40 & 05.9 .2014 & 2 & 5 \\
\hline \multirow[t]{6}{*}{ 2-Irmaksırtı } & 30 & 03.6 .2013 & 2 & 6.6 \\
\hline & 100 & 23.4 .2014 & 9 & 9 \\
\hline & 84 & 01.6 .2014 & 8 & 9.5 \\
\hline & 44 & 28.6.2014 & 11 & 25 \\
\hline & 14 & 28.6.2014 & 0 & 0 \\
\hline & 20 & 20.9 .2014 & 0 & 0 \\
\hline \multirow{7}{*}{ 3-Kızilot } & 46 & 27.3 .2013 & 3 & 6.5 \\
\hline & 87 & 01.6 .2014 & 5 & 5.7 \\
\hline & 118 & 24.6 .2014 & 6 & 5 \\
\hline & 39 & 27.6 .2014 & 2 & 5.1 \\
\hline & 14 & 28.6 .2014 & 0 & 0 \\
\hline & 12 & 06.9 .2014 & 0 & 0 \\
\hline & 2 & 20.9 .2014 & 0 & 0 \\
\hline \multirow[t]{3}{*}{ 4-Havaalan1 } & 66 & 24.4 .2014 & 6 & 9.1 \\
\hline & 109 & 01.6 .2014 & 4 & 3.6 \\
\hline & 89 & 28.6.2014 & 6 & 6.7 \\
\hline \multirow{3}{*}{ Kastamonu } & 16 & 14.4.2013 & 0 & 0 \\
\hline & 113 & 26.4 .2014 & 1 & 0.8 \\
\hline & 201 & 28.6.2014 & 4 & 2 \\
\hline Kocaeli & 71 & 02.5 .2014 & 0 & 0 \\
\hline Akyazı & 62 & 03.5.2014 & 0 & 0 \\
\hline Bilecik & 65 & 19.5 .2014 & 0 & 0 \\
\hline Bursa & 65 & 17.5 .2014 & 2 & 3.1 \\
\hline Bolu & 103 & 16.5 .2014 & 5 & 4.8 \\
\hline Total & 1,728 & & 78 & 4.51 \\
\hline
\end{tabular}

infection rates for both pathogens were variable between the localities (Table 1) and reached 25\% in some localities. We did not observe any infection in three (Kocaeli, Akyazı and Bilecik) of the investigated localities. More details on the occurrence and distribution of the microsporidian pathogens are given in Table 1.

\section{Discussion}

In this study, two microsporidian pathogens, Isolate 1 and Isolate 2, are presented from C. aurata populations for the first time. To date there is no microsporidian report from $C$. aurata. Microsporidia have been known relatively host specific and the host affinity can be accepted as a valid taxonomic character for microsporidia taxonomy (Sprague et al. 1992). It seems that at least one Microsporidium species infects C. aurata. On the other hand, spore morphology and size, host locality and infection rates are also important characteristics to discriminate microsporidia infecting insects (Larsson 1999, Yaman \& Radek 2003, Yaman et al. 2008b). Two microsporidian pathogens found in the $C$. aurata populations show considerable differences from each other in the spore shape and size (Table 2) as well as in infection capability ( 1.7 to $5 \%$ Isolate 1 and 0.8 to $25 \%$ for Isolate 2) and locality (Isolate 1 in Vezirköprü and Isolate 2 in the rest of the investigated localities) of the host population. Similarly, two new microsporidia were identified from the populations of Chaetocnema tibialis (Illiger) (Coleop- 
Table 2. Microsporidian species first found in Chrysomelidae (Coleoptera).

\begin{tabular}{|c|c|c|c|}
\hline Species & $\begin{array}{l}\text { Spore size and } \\
\text { shape }(\mu \mathrm{m})\end{array}$ & Infected organ & Host \\
\hline $\begin{array}{l}\text { Nosema phyllotretae } \\
\text { Weiser, } 1961\end{array}$ & $4.2 \times 2-3$ & Adipose body & $\begin{array}{l}\text { Phyllotreta atra } \\
\text { Phyllotreta undulata }\end{array}$ \\
\hline $\begin{array}{l}\text { Nosema gastroideae } \\
\text { Hostounský \& Weiser, } 1973\end{array}$ & $3-4.8 \times 2.5-3$ & Overall infestation & $\begin{array}{l}\text { Gastrophysa polygoni and } \\
\text { several experimental hosts }\end{array}$ \\
\hline $\begin{array}{l}\text { Nosema polygrammae } \\
\text { Hostounský \& Weiser, } 1975\end{array}$ & $4.8 \times 2.05$ & Gut & $\begin{array}{l}\text { Polygramma } \\
\text { undecemlineata }\end{array}$ \\
\hline $\begin{array}{l}\text { Nosema equestris } \\
\text { Hostounský \& Weiser, } 1980\end{array}$ & $4-5 \times 3$ & General infestation & $\begin{array}{l}\text { Gastrophysa viridula } \\
\text { Leptinotarsa decemlineata }\end{array}$ \\
\hline $\begin{array}{l}\text { Nosema couilloudi } \\
\text { Toguebaye \& Marchand, } 1984\end{array}$ & $3.4-4 \times 1-1.5$ & Gut & Nisotra sp. \\
\hline $\begin{array}{l}\text { Nosema birgii } \\
\quad \text { Toguebaye \& Marchand, } 1986\end{array}$ & $6.2 \times 3.5$ & $\begin{array}{l}\text { Eggs and general } \\
\text { infestation, larvae } \\
\text { and imago }\end{array}$ & Mesoplatys cincta \\
\hline $\begin{array}{l}\text { Nosema nisotrae } \\
\quad \text { Toguebaye \& Marchand, } 1989\end{array}$ & $5.8 \times 3.1$ & General infestation & Nisotra sp. \\
\hline $\begin{array}{l}\text { Nosema galerucellae } \\
\quad \text { Toguebaye \& Bouix, } 1989\end{array}$ & $4.95 \times 2.89$ & $\begin{array}{l}\text { Gut principally, } \\
\text { adipose body, } \\
\text { muscles, tracheae, } \\
\text { malpighian tubules }\end{array}$ & Galerucella luteola \\
\hline $\begin{array}{l}\text { Nosema chaetocnemae } \\
\text { Yaman \& Radek, } 2003\end{array}$ & $3.52 \times 2.09$ & $\begin{array}{l}\text { Gut, tracheae, } \\
\text { muscles, mal- } \\
\text { pighian tubules }\end{array}$ & Chaetocnema tibialis \\
\hline $\begin{array}{l}\text { Nosema tokati } \\
\text { Yaman et al., } 2008\end{array}$ & $3.82 \times 1.3$ & Malpighian tubules & Chaetocnema tibialis \\
\hline $\begin{array}{l}\text { Nosema leptinotarsae } \\
\quad \text { Lipa, } 1968\end{array}$ & $2-5 \times 1.9-3.3$ & Haemolymph & Leptinotarsa decemlineata \\
\hline $\begin{array}{l}\text { Nosema leptinotarsae } \\
\text { Yaman et al., } 2011\end{array}$ & $4.69 \times 2.43$ & General infestation & Leptinotarsa decemlineata \\
\hline $\begin{array}{l}\text { Unikaryon bouixi } \\
\quad \text { Toguebaye \& Marchand, } 1983\end{array}$ & $\begin{array}{l}\text { ovoid } \\
1.6-2.5 \times 1.5-1.6\end{array}$ & $\begin{array}{l}\text { Gut and malpighian } \\
\text { tubules }\end{array}$ & Euryope rubra \\
\hline $\begin{array}{l}\text { Unikaryon matteii } \\
\quad \text { Toguebaye \& Marchand, } 1984\end{array}$ & $\begin{array}{l}\text { ovoid } \\
3.72 \times 1.96\end{array}$ & $\begin{array}{l}\text { gut, malpighian } \\
\text { tubules and muscles }\end{array}$ & Nisotra $s p$. \\
\hline $\begin{array}{l}\text { Unikaryon nisotrae } \\
\quad \text { Toguebaye \& Marchand, } 1986\end{array}$ & $\begin{array}{l}\text { ovoid } \\
2.33 \times 1.66\end{array}$ & $\begin{array}{l}\text { gut and adipose } \\
\text { tissue }\end{array}$ & Nisotra sjoestedti \\
\hline $\begin{array}{l}\text { Unikaryon phyllotretae } \\
\text { Yaman et al., } 2010\end{array}$ & $\begin{array}{l}\text { spherical to } \\
\text { ovoid, } 3.80 \times 1.90\end{array}$ & Malpighian tubules & Phyllotreta undulata \\
\hline $\begin{array}{l}\text { Microsporidium sp. } 1 \\
\quad \text { (this study) }\end{array}$ & $\begin{array}{l}\text { ovoid } \\
3.66-5.66 \times 1.35-2.22\end{array}$ & Haemolymph & Crepidodera aurata \\
\hline $\begin{array}{l}\text { Microsporidium sp. } 2 \\
\quad \text { (this study) }\end{array}$ & $\begin{array}{l}\text { Slightly curled } \\
2.44-3.55 \times 1.25-1.55\end{array}$ & Haemolymph & Crepidodera aurata \\
\hline
\end{tabular}

tera; Chrysomelidae) in different localities (Yaman \& Radek 2003, Yaman et al. 2008b). Yaman et al. (2008b) observed different infection rates between Nosema chaetocnemae Yaman \& Radek and N. tokati Yaman, Radek \& Toguebaye, infecting C. tibialis populations in Turkey.

There are different microsporidian species recorded from the members of the family Chrysomelidae. The results show that the microsporidian pathogens presented here differ from micro- sporidia infecting the family Chrysomelidae in spore size, type of infected tissue, infection rate, host affinities and locality of the host population (Table 2). The Isolate 2 from C. aurata clearly differs in spore size from microsporidian species infecting chrysomelids (Table 2). To identify both isolates at the species level we need to complete some morphological and ultrastructural studies on the different life stages and molecular phylogeny on the microsporidian pathogens in- 
fecting chrysomelids. For now, we consider our organisms, tentatively classified in the collective group Microsporidium, to be two distinct, undescribed species and call Isolate 1 as Microsporidium sp.1 and Isolate 2 as Microsporidium sp. 2. Further studies, however, are needed to finally resolve the taxonomic status of the new microsporidia from C. aurata. Here we are focused on the occurrence and distribution of Microsporidium sp. 1 and Microsporidium sp. 2 in the $C$. aurata populations from several localities in a wide geographical area in Turkey.

Microsporidial infections were observed in the seven of ten investigated localities in the both years (Table 1). Yaman (2007) observed Nosema meligethi infection in only two of the seventeen Meligethes aeneus (Fabricius) (Coleoptera: Nitidulidae) populations investigated in Turkey. In another study, Yaman (2008) found Nosema infection in Chaetocnema tibialis (Coleoptera: Chrysomelidae) adults from two of the ten localities. Further, Aydin et al. (2009) observed Nosema phyllotretae Weiser infection in Phyllotreta atra (Fabricius) (Coleoptera: Chrysomelidae) populations from only one of the five localities. The results confirm that the microsporidian pathogens in the present study have an extensive distribution in the populations of $C$. aurata. However, we did not observe any infection in $C$. aurata populations from the three localities (Kocaeli, Akyazı and Bilecik) which are close to each other geographically (Fig. 1).

Total infection rate for both microsporidia was $4.51 \%$, varying among the localities from 0.8 to $25 \%$ (Table 1 ). Potentially high infection is promising for biological pest control. Crepidodera aurata has one generation per year. Beetles overwinter as imago and lay eggs in spring. Larvae develop during summer and in the end of August, and the new generation appears (Aslan et al. 1999, Urban 2011). Therefore, the beetles of $C$. aurata occur on poplars and willows from April to October and skeletonize leaves of these plants. During this developmental period, any disease factor affecting population density is of great important. The microsporidia presented here are the first pathogens recorded from $C$. aurata. This study confirms that the pathogens are found widely in the populations of $C$. aurata as natural potentially suppressing factor.
Acknowledgements. The study was financially supported as a research project by the Scientific and Technological Council of Turkey (1120807). Authors are thankful to the reviewers for their kind efforts to improve the manuscript.

\section{References}

Aslan, İ., Gruev, B. \& Özbek, H. 1999: A preliminary review of the subfamily Alticinae (Coleoptera, Chrysomelidae) in Turkey. - Turkish Journal of Zoology 23: 373-414.

Aslan, İ., Özbek, H. \& Warchalowski, A. 2004: Five new records, new localities and new host plants for the Turkish flea-beetle fauna (Coleoptera: Chrysomelidae: Alticinae). - Entomologica Fennica 15: 138-141.

Aslan, İ. \& Warchalowski, A. 2005: Longitarsus ozbeki sp n., a new species from Asia Minor (Coleoptera : Chrysomelidae: Alticinae). - Entomologica Fennica 16: 221-224.

Aydın, Ç., Yaman, M. \& Tosun, O. 2009: Distribution of Nosema phyllotretae (Microspora, Nosematidae) Weiser, 1961 in populations of Phyllotreta atra (Coleoptera, Chrysomelidae) in Turkey. - Türkiye Parazitoloji Dergisi 32: 165-168.

Baselga, A. \& Novoa, F. 2007: Diversity of Chrysomelidae (Coleoptera) at a mountain range in the limit of the Eurosiberian region, northwest Spain: species richness and beta diversity. - Entomologica Fennica 18: $65-73$.

Bukejs, A. 2009: To the knowledge of flea beetles (Coleoptera: Chrysomelidae: Alticinae) of the fauna of Latvia. - Acta Zoologica Lituanica 19: 109-119.

Czerniakowski, Z. W. 2005: Noxious insects in energy willow coppice nurseries. - Progress in Plant Protection 45: 19-24.

Ertürk, Ö., Yaman, M. \& Aslan, İ. 2008: Effects of four soil-originated Bacillus spp. on the Colorado potato beetle, Leptinotarsa decemlineata (Say). - Entomological Research 38: 135-138.

Hokkanen, H. M. T., Lipa J. J. 1995: Occurrence and dynamics of Nosema meligethi (Microsporida) in populations of Meligethes aeneus (Coleoptera, Nitidulidae) in Finland. - Entomologica Fennica 6: 11-18.

Hostounsk1, Z. \& Weiser, J. 1973: Nosema gastroideae sp. n. (Nosematidae, Microsporidia) infecting Gastrophysa polygoni and Leptinotarsa decemlineata (Coleoptera: Chrysomelidae). - Acta Entomologica Bohemoslovaca 70: 345-350.

Hostounsk1, Z. \& Weiser, J. 1975: Nosema polygrammae sp. n. and Plistophora fidelis sp. n. (Microsporidia, Nosematidae) infecting Polygramma undecimlineata (Coleoptera: Chrysomelidae) in Cuba. - Vistník Èeskoslovenské Spoleènosti Zoologické 39: 104-110.

Hostounsk1, Z. \& Weiser, J. 1980: A microsporidian infection in Otiorrhynchus equestris (Coleoptera, Curculionidae) in Cuba. - Vistník Ėeskoslovenské Spoleènosti Zoologické 44: 160-165.

Larsson, J. I. R. 1999: Identification of microsporidia. Acta Protozoolologica 38: 161-197. 
Martin, P. A. W., Blackburn, M. \& Shropshire, A. D. S. 2004: Two new bacterial pathogens of colorado potato beetle (Coleoptera: Chrysomelidae). - Journal of Economic Entomology 97: 774-780.

Mikhailov, Y. E. \& Hayashi, M. 2002: Chrysomelidae of Sakhalin II. - Entomological Review of Japan 57: $29-46$.

Poinar, G. O. 1988: Nematode parasites of Chrysomelidae. - In: Jolivet, P., Petitpierre, E. \& Hsiao, T. H. (Eds.), Biology of Chrysomelidae: 433-448. Kluwer Academic Publisher, Dordrecht, Boston, London. 615 pp.

Sprague, V., Becnel, J. J. \& Hazard, E. I. 1992: Taxonomy of Phylum Microspora. - Critical Reviews in Microbiology 18: 285-395.

Theodorides, J. 1988: Gregarines of Chrysomelidae. - In: Jolivet, P., Petitpierre, E. \& Hsiao, T. H. (Eds.), Biology of Chrysomelidae: 417-431. Kluwer Academic Publisher, Dordrecht, Boston, London. 615 pp.

Toguebaye B. S., Marchand B. \& Bouix G. 1988: Microsporidia of the Chrysomelidae. - In: Jolivet, P., Petitpierre, E. \& Hsiao, T. H. (Eds.), Biology of Chrysomelidae: 399-416. Kluwer Academic Publisher, Dordrecht, Boston, London. 615 pp.

Toguebaye, B.S. \& Bouix, G. 1989: Nosema galerucellae sp.n., Microsporidian (Protozoa, Microspora), parasite of Galerucella luteola Müller (Chrysomelidae, Coleoptera): development cycle and ultrastructure. European Journal of Protistology 24: 346-353.

Toguebaye, B. S. \& Marchand, B. 1984: Nosema couilloudi n.sp., microsporidie parasite de Nisotra sp. (Coleoptera, Chrysomelidae): Cytopathologie et ultrastructure des stades de developpement. - Protistologica 20: 357-365.

Toguebaye, B. S. \& Marchand, B. 1986: Etude d'une infection microsporidienne due a Nosema birgii n.sp. (Microsporida, Nosematidae) chez Mesoplatys cincta Olivier, 1790 (Coleoptera, Chrysomelidae). — Zeitschrift für Parasitenkunde 72: 723-737.

Toguebaye, B. S. \& Marchand, B. 1989: Observations en microscopie electronique a transmission des stades de developpement de Nosema nisotrae sp.n. (Microsporida, Nosematidae) parasite de Nisotra sp. (Coleoptera, Chrysomelidae). - Archiv für Protistenkunde. 137: 69-80.

Urban, J. 2011: Occurrence, bionomics and harmfulness of Crepidodera aurata (Marsh.) (Coleoptera, Alticidae). - Acta Universitatis Agriculturae et Silviculturae Mendelianae Brunensis 59: 263-278.

Weiser, J. 1961: Die Mikrosporidien als Parasiten der Insekten. - Monographien zur Angewandten Entomologie. 17: 1-149.
Yaman, M. 2002a: Howardula phyllotretae (Tylenchida: Allantonematidae), a nematode parasite of Phyllotreta undulata and Phyllotreta atra (Coleoptera : Chrysomelidae) in Turkey. - Journal of Asia-Pasific Entomology 5: 233-235.

Yaman, M. 2002b: Gregarina phyllotretae Hoshide 1953, a protozoan parasite of the flea beetles, Phyllotreta undulata and $P$. atra (Coleoptera: Chrysomelidae) in Turkey. - Applied Entomology and Zoolology 37: 649-653.

Yaman, M., 2004: A newly recorded gregarine parasite of Chaetocnema tibialis (Coleoptera, Chrysomelidae) from Turkey. - Turkish Journal of Zoology 28: 9596.

Yaman, M. 2007: Distribution of Nosema meligethi I. \& R. (Microsporida) in populations of Meligethes aeneus (Coleoptera: Nitidulidae) in Turkey. — Entomological Research 37: 298-301.

Yaman, M. 2008: First results on the distribution of Nosema chaetocnemae (Microspora) in the populations of Chaetocnema tibialis (Coleoptera, Chrysomelidae) in Turkey. - Türkiye Parazitoloji Dergisi 32: 9498.

Yaman, M. \& Radek, R. 2003: Nosema chaetocnemae sp. n., a microsporidian (Microspora; Nosematidae) parasite of Chaetocnema tibialis (Chrysomelidae, Coleoptera). - Acta Protozoologica 42: 231-237.

Yaman, M., Tosun, O. \& Aslan, I. 2008a: On the occurrence of gregarine parasite from Psylloides cupreus Koch 1803 (Coleoptera: Chrysomelidae) of Turkey. North-Western Journal of Zoology 4: 167-172.

Yaman, M., Radek, R. \& Toguebaye, B. 2008b: A new microsporidian of the genus Nosema, parasite of Chaetocnema tibialis (Coleoptera: Chrysomelidae) from Turkey. - Acta Protozoologica 47: 279-285.

Yaman, M., Radek, R., Weiser, J. \& Toguebaye, B. 2010: Unikaryon phyllotretae sp. n. (Protista, Microspora), a new microsporidian pathogen of Phyllotreta undulata (Coleoptera; Chrysomelidae). — European Journal of Protistology 46: 10-15.

Yaman, M., Radek, R., Linde, A., Özcan, N. \& Lipa, J. J. 2011a: Ultrastructure, characteristic features and occurrence of Nosema leptinotarsae Lipa 1968, a microsporidian pathogen of Leptinotarsa decemlineata (Coleoptera: Chrysomelidae). - Acta Parasitolologica 56: $1-7$

Yaman, M., Tosun, O., Lipa, J. J. \& Aslan, İ. 2011b: The first records of a gregarine pathogen and a mermithid parasite from Chrysolina fastuosa (Scopoli 1763) (Coleoptera: Chrysomelidae). — North-Western Journal of Zoology 7: 105-111. 